\title{
How Private Equity Funds Boost the Competitiveness of Companies (Based On Polish Cases)
}

\author{
Ilona FAŁAT-KILIJAŃSKA and Piotr LUTY \\ Wroclaw University of Economics, Department of Finance \\ ul. Komandorska 118-120, 53-345 Wrocław, Poland
}

Correspondence should be addressed to: Ilona FAŁAT-KILIJAŃSKA; i.falat-kilijanska@ue.wroc.pl

Received date: 1 November 2018; Accepted date: 11 January 2019; Published date: 30 April 2019

Academic Editor: Elena Sira

Copyright @ 2019. Ilona FAŁAT-KILIJAŃSKA and Piotr LUTY. Distributed under Creative Commons CC-BY 4.0

\begin{abstract}
In order for a company to develop, it needs to be innovative. However, the company must first reach the right level of employment and turnover. In turn, in order for a company to reach this appropriate level, sufficient capital resources are necessary. A private equity fund provides primarily this last element, thus becoming the company's largest shareholder. The object of this article is to show the influence that private equity investments have on companies' activities, and especially on the growth of competitiveness and innovation performance. The study conducted by authors shows that a private equity fund has significant influence on the strategic decisions made by the company management, the direction of its development and the future ownership structure. The study also made it possible to determine the role that a private equity fund, being a shareholder of a given company, plays in creating its market position.

An important source of empirical data is the author's own surveys and interviews with representatives of shareholding companies, as well as with private equity fund managers. Years of research: 1998 - 2016.The study involved 59 companies, which account for $11 \%$ of the entire population were taken into consideration. Several research methods were used in the study: the descriptive method, the comparative analysis method, the critical analysis method and the synthesis of conclusions method. Moreover, analysis of the results obtained within the study and the statistical data analysis were conducted.
\end{abstract}

Keywords: private equity investments, venture capital, competitiveness, innovation.

Cite this Article as: Ilona FAŁAT-KILIJAŃSKA and Piotr LUTY (2019)," How Private Equity Funds Boost the Competitiveness of Companies (Based On Polish Cases)", Journal of Financial Studies \& Research, Vol. 2019 (2019), Article ID 630543, DOI: 10.5171/2019.630543 


\section{Introduction}

The success of a given company depends on how successful it is at competing. The biggest barrier to the development of any business entity, and thus a barrier to being innovative and competitive, often consists in insufficient financial resources. One of the alternative ways of financing economic activity is the use of private equity capital. The aim of this article is to show the influence that private equity investments have on companies' activities, and especially on the growth of competitiveness and innovation performance. The study conducted by authors shows that, by becoming a company's major shareholder, a private equity fund has significant influence on the strategic decisions made by the company management, the direction of its development and the future ownership structure. The study also made it possible to determine the role that a private equity fund, being a shareholder of a given company, plays in creating its market position.

The primary source of empirical data is author-prepared surveys and interviews with both representatives of shareholding companies and private equity fund managers. The study covered the years from 1998 to 2016. Prior to commencing the study, a complete phone and address database containing 200 Polish enterprises using private equity capital was prepared. Before emailing the survey form to all the 200 companies, the appropriate people's agreement to participate in the study was obtained. In order to collect and analyse the data, a special application had been developed to enable the respondents to complete and send back the questionnaire via a website. The application was also used to collect all the survey results in a database. The study involved 59 companies, 45 of which sent back the completed questionnaire and 14 provided the answers in a telephone conversation or sent the required information via email. In analysing the survey results, only those answers which account for $11 \%$ of the entire population were taken into consideration (according to statistical data of the Polish Private Equity Association (PSIK), at the end of 2013, there were about 500 Polish enterprises using private equity funds).

Several research methods were used in the study: the descriptive method, the comparative analysis method, the critical analysis method and the synthesis of conclusions method. Moreover, an analysis of the results obtained within the study and the statistical data analysis were conducted.

\section{Competitiveness}

In order to define competitiveness, it is insufficient to state that it is a characteristic of participants in the rivalry. Usually, it is the effects of competitiveness that are defined, namely; competitive advantage and position. In her analysis of company competitiveness, the author adopted the definition of competitiveness proposed in 1994 at the World Economic Forum in Lausanne. Competitiveness was defined there as "the ability of a country or company to produce greater wealth than their competitors in the world market" (cf. The Word Competitiveness Report 1994, p. 18). It is a very broad definition, in which competition is a relative term. Although the greatest authority in the field of building competitive advantage, M. E. Porter, has not provided a definition of competitiveness in express terms, the context of his statements suggests that he perceives competitiveness of nations as their ability to create conditions conducive to the development of international competitiveness of those nations' industries and international competitiveness of companies operating in particular domestic sectors, and not just as their ability to be literal entities of the competition process. This ability is dependent on four interrelated systems. These systems are so significant that Porter refers to them as 'diamonds' of national competitive advantage, and are formed through: 
1. factorial conditions, i.e. a country's abundance of production and infrastructure factors necessary to compete in a given industry;

2. demand conditions, i.e. domestic demand for products and services of a given sector;

3. related and supporting industries, namely; the existence in the country of supply sectors and allied industries meeting the requirements of international competition;

4. companies' strategies, their structure and the level of rivalry between them, i.e. the state-created conditions that define the framework for the formation and operation of business entities and the nature of competition in the internal market (Porter 1985, pp. 71-71).

Significant elements of building competitive advantage by a country, especially in the case of the level of an economy's attractiveness for investors, include, according to Porter, components of resource factors, which encompass:

- human resources (number, qualifications, labour cost, the level of work ethic);

- physical resources (abundance, quality, availability of resources, climate, geographical location);

- knowledge resources (number and quality of higher education facilities and research institutes, trade associations and societies, databases, collections of scientific literature, as well as the opportunity to develop research works);

- capital resources (the volume of resources, the cost of acquiring capital and legal considerations having an impact on the forms of acquiring capital);

- infrastructure - types of infrastructure and costs of its use (transport, communication, delivery charges, capital transfer fees, healthcare, housing, and cultural institutions) (Porter 1985, pp. 73-75).

Although Porter's list of 'diamonds' of competitive advantage was made in reference to countries, we can also apply these 'diamonds' to smaller-sized entities, such as enterprises. And just as well, we can define the factors that allow a company to achieve competitive advantage, e.g. access to cheaper sources of supply, better product quality, unique technology, efficient service, and optimal location. But the factor most significantly influencing a company's competitiveness level in today's economy is innovativeness. A company's innovativeness consists in the human resources it has, that is, in the quality of intellectual capital. A contemporary company has to possess one important characteristic - innovation dynamism. It is the ability to create innovations in every area of operation, to creatively use innovative achievements of others and to effectively implement and develop them. It is also the ability to develop the market offer, in terms of both quantity and quality, based on these innovations and a sense of the needs of the market itself (cf. Kolka 2005).

\section{Private Equity Capital}

Private equity is investments in the private equity market, aimed at obtaining earnings through capital gain. It is the purchase of shares of unlisted companies. Private equity funds invest in mature companies seeking new development opportunities, as well as in new ventures. This term applies also to the instances of capital being raised by enterprises through the so-called management buy-out (cf. Rocznik 2002, p. 4). Private equity investments are obtained for the purposes of new product or technology development, increasing working capital, improving the balance or other major investment expenditures. Commonly used is the term 'venture capital', which is part of private equity. These are investments made in the early stages of a business' life cycle,

Ilona FAŁAT-KILIJAŃSKA and Piotr LUTY (2019), Journal of Financial Studies \& Research, DOI: $10.5171 / 2019.630543$ 
intended for its start-up or expansion of its operations, usually in amounts smaller than in the case of private equity. These two terms are often used interchangeably. Literature offers various definitions of the private equity and venture capital terms. Most often, the feature that helps to distinguish between them is the author's country of origin. Continental Europe, the United Kingdom and the United States represent different approaches to private equity and venture capital investments. Although private equity investment is a concept broader than venture capital and the two may mean investments of very different characters, these terms are often used interchangeably. For the purposes of this article, authors use the term 'private equity' in its broadest sense.

First Polish investments took place in 1990, when - thanks to an aid programme for Central Europe adopted by the Bush administration - the Polish-American Enterprise Fund (PAEF) was created, amounting to 240 million dollars. Since then, it has founded seven private equity funds and one venture capital fund, thus becoming the largest investment company in Poland Enterprise Investors (www.ei.com.pl). Currently, there are about 55 fund management companies still present in the Polish market, predominantly of the private equity-type. The value of the capital managed by them is estimated to more than 14 billion euros, over 5.6 billion of which were invested in Poland by the end of 2015, injecting capital in about 600 Polish companies (on the basis of data published on the website of the Polish Private Equity Association, http://www.ppea.org.pl). The companies chosen for investment projects are active in internet technology, IT, telecommunications, biotechnology and nanotechnology. The most interesting Polish investments of private equity funds in these fields include: Travelplanet (e-commerce), GeoTec (software), BillBird (financial settlements), Big Vent (software), BankCom (telemarketing) and Bioton (biotechnology), Wirtualna Polska (internet portal).

\section{Methods for measuring the level of competitiveness}

The definition of competitiveness adopted in Lausanne defines the concept of competitiveness as the ability to effectively pursue objectives in the competitive market arena; the level of competitiveness is reflected in an entity's efficiency in achieving its objectives. Efficiency is understood here in the praxeological sense, i.e. as simultaneous presence of the three main factors of the efficient operation: effectiveness, profitability and economy. The obtained results of operations constitute a generalised indication of the competitiveness level. The selection of results and their evaluation depend on the entities interested in them - the organisation's "strategic supporters," i.e. the stakeholders:

1. shareowners;

2. customers or buyers;

3. employees;

4. suppliers.

Each of the above-enumerated groups will follow different criteria in assessing the level of a company's competitiveness. For the purposes of this paper, the behavioral patterns of two groups (customers and suppliers) have been omitted, and the competitiveness level of companies using private equity funds has been evaluated from two points of view - owners and employees'.

Owners are primarily interested in the income that they can achieve through their company shareholdings. This income comes primarily from the increases in the company's value, which are evident in the increases in the share price and the dividends received (cf. Rapaport 1999, p. 15). Employees are mainly interested in work and remuneration conditions. What is important for them is the form of employment and the amount and system of remuneration, conditions of physical and mental work environment, conditions for fulfilling needs and developing. The higher the level in the 
employment hierarchy, the greater the need to fulfil higher-order needs (having power, creating reality, or appreciating professionalism) (cf. Stankiewicz 2005, pp. 41-42).

Therefore, as a co-owner of a given company, a private equity fund focuses primarily on pursuing profit resulting from increases in a portfolio company's value. The factors that build up the value of a company include primarily: a healthy cash flow, the creation and development of new products, market acceptance and a highly qualified staff.

The literature on the issue mentions not only financial factors, but also marketing and intangible ones. Marketing factors consist in building customer loyalty, finding ways of acquiring new customers, winning new markets, gaining new channels of distribution, mergers and acquisitions, globalisation. The intangible factors group includes the intellectual capital, company's innovation capabilities, brand strength, internal communication, organisational culture, information systems, social reputation and efficient logistics strategies (cf. Herman, Szablewski 1999). When in search for factors affecting the creation of the value of a company operating in an economy based largely on knowledge, the management needs to focus primarily on intangible factors. They should attach more importance to intellectual capital, information technology capital and organisational capital.

All the above-listed factors constitute the most important areas within the "watchful eye" that the private equity funds keep on their portfolio companies.

\section{Research Results}

The most important group of generators of business value growth are, as previously mentioned, the financial factors. Cash flow, the volume of sales revenues (turnover), the level of EBIT operating profit and net profit, sales and the share of exports in total sales as well as the operating profit and net profit per one employee are all measurable and comparable. Net profit, however, was omitted in the study, and all ratios were based on sales revenues and EBIT operating profit, as they provide a better picture of the effectiveness and efficiency of an enterprise's activity. Net profit may in fact include various other - and frequently random - values that are not related to the core business of the company (for instance, net financial result). Comparative analysis of the above-mentioned values provides a tangible basis for assessing the economic effect of private equity funds' presence among the shareholders. Due to limitations in obtaining complete financial information from the surveyed companies, the cash flow analysis was based on the respondents' answers only.

The surveys conducted by the author clearly show that, in most cases, private equity capital allows companies to immediately improve their financial liquidity. Ingrowing the cash flow was indicated by as many as $76 \%$ of the respondents (fig. 1). Half of the companies included in the study used the received funds to repay their debts. Having a new investor, entities may settle their liabilities in a timely manner, and managers can focus on introducing new management accounting standards. Companies have vacant financial resources that can be spent on the purchase of modern IT systems (42\% of the responses), through which the efficiency of financial analysts' work increases significantly. This in turn leads to yearly improvements in the efficiency of managing the entire company and its results. The fund itself dictates how to present the results and prepare reports (usually monthly ones). 


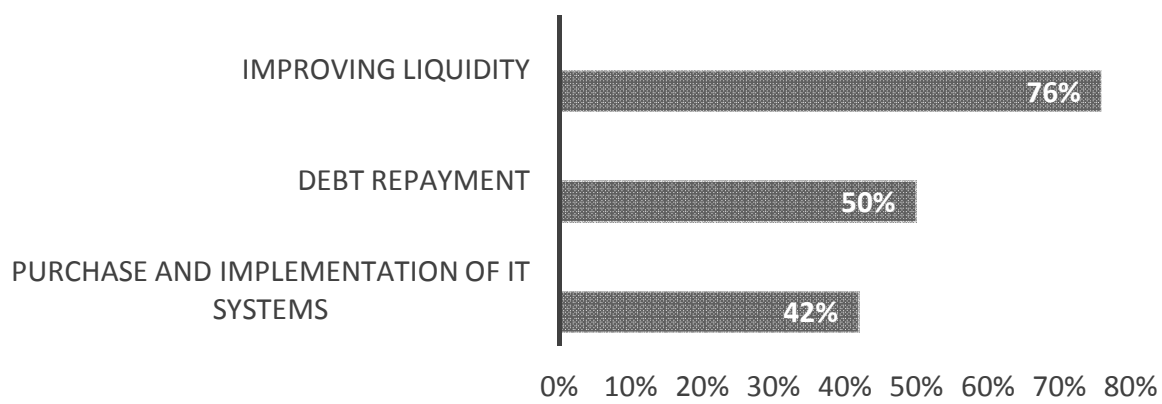

Fig. 1: Primary allocation of private equity capital in connection with the Finances

Source: Own work based on the answers to a survey prepared by authors.

Changes in the levels of a company's turnover and in the amounts of operating profit it achieves depend not only on the individual characteristics of the company itself, but also - and to the same extent - on the conditions prevailing on the market at a given moment in time. In order to assess whether a private equity fund's investment has any influence on the company's performance, the survey probed how the respondents assess the changes in the level of their company's turnover as well as the changes in the amount of the EBIT operating profit achieved by their companies in comparison to those occurring in rival businesses. Research results regarding private equity capital's contribution to operating profit growth in Polish companies are not conclusive. The distribution of answers to the question as to whether the level of EBIT operating profit achieved by the company through the use of private equity capital rose by more than that of competing businesses is symmetric. 39\% of the respondents stated that the company's EBIT increased by more than that of their competition, 32\% answered "no," and 29\% were not able to assess this phenomenon (fig. 2). A majority, however, although small, evaluated private equity capital's role in achieving better business performance as positive.

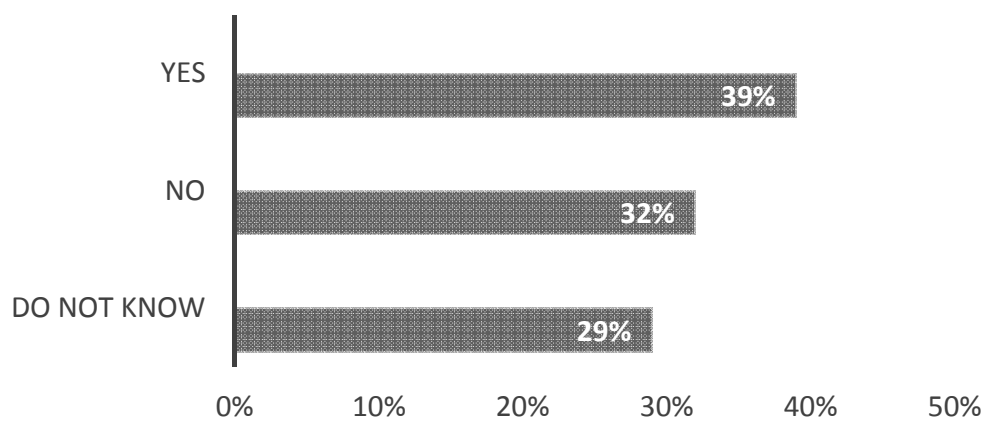

Fig. 2: Did the level of EBIT operating profit achieved by your company through the use of private equity capital rise by more than that of competing businesses?

Source: Own work based on the answers to a survey prepared by authors.

Ilona FAŁAT-KILIJAŃSKA and Piotr LUTY (2019), Journal of Financial Studies \& Research, DOI: $10.5171 / 2019.630543$ 
Managers of companies using private equity financing are of the opinion that after the fund's investment, the company's activity in international markets increases, as evidenced by an increase in exports. Detailed study findings, however, were a source of some surprise. In some companies, the share of export turnover did actually grow significantly (on an average, by $30 \%$ ), but these belong to a minority (merely $3 \%$ of the responses). In the case of one third of the companies, after the entry of the private equity investor, there occurred a decrease in exports, and in $64 \%$ of the cases, the exports level did not change (fig. 3). Survey results were so surprising that they have been additionally verified in phone conversations with most of the respondents.

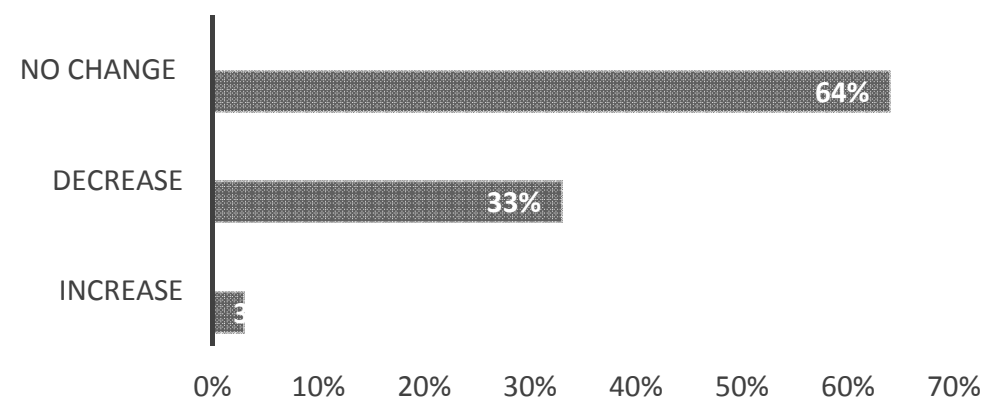

Fig. 3: Changes in the level of exports in Polish companies using private equity financing, compared to that in the period before the fund's entry

Source: Own work based on the answers to a survey prepared by authors.

An increase in exports was indicated only by the largest companies (e.g. Polfa Kutno) and very few of the smaller entities (e.g. Bioton). In many of the surveyed companies that were at maturity stage already before the fund's investment, the exports volume was high, reaching as much as $60 \%$, but after the entry of the investor, all production is sold on the domestic market. Companies being in early stages of their corporate life were not exporters at the time of the investor's entry. Although this fact might seem very negative, after a careful analysis of the profile of all companies participating in the survey, their success can actually be considered. As the share of a company's exports in its sales revenues decreases (perhaps even to zero), the share of that company in the Polish market increases. This means an increase in the competitiveness of companies using private equity capital, but only among domestic companies. It is estimated that, despite its large increase in recent years, the domestic demand will continue to grow. Improving the quality of Polish products can ensure absolute marketability of goods produced by Polish manufacturers while maintaining an appropriate pricing policy. As survey results show, through the use of private equity capital, companies - having no basic problems (e.g. with financial liquidity) focus on the quality and innovativeness of their products. These domestic companies are often the first ones to place a product on the Polish market.

Analysis of the net profit margin per employee in companies using private equity capital depicts its growth in comparison to the results obtained by the competition (fig. 
4). $61 \%$ of the respondents indicated that after the investor's entry, there occurred in their company an increase in labour productivity, $37 \%$ of whom believe it to have increased by more than half, compared to the situation prevailing at the time of the private equity investment.

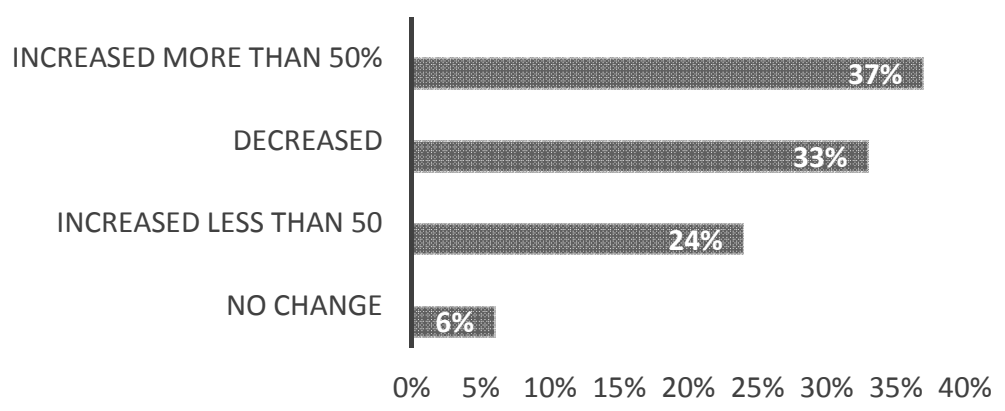

Fig. 4: Changes in the net profit margin per employee after the private equity investment, compared to that of the competition, in the respondents' assessment

Source: Own work based on the answers to a survey prepared by authors.

One-third of the respondents think that the level of net profit per employee fell after the fund's investment. In these cases, the number of employees grew more than the net profit level.

One of the components accounting for a company's success is its product: degree of its innovativeness, its quality and its price. Polish entrepreneurs participating in the survey identified four major ways of using private equity capital that are closely connected with the company's products (fig. 5 ). The most common way of disbursing funds is by investing in new technologies (81\% of the answers). Ranking second in popularity are activities that help to develop the existing product range $(79 \%)$, followed by widening the product range. A considerable part of the capital is also allocated to implement a number of programmes to improve the quality of products offered by the company.

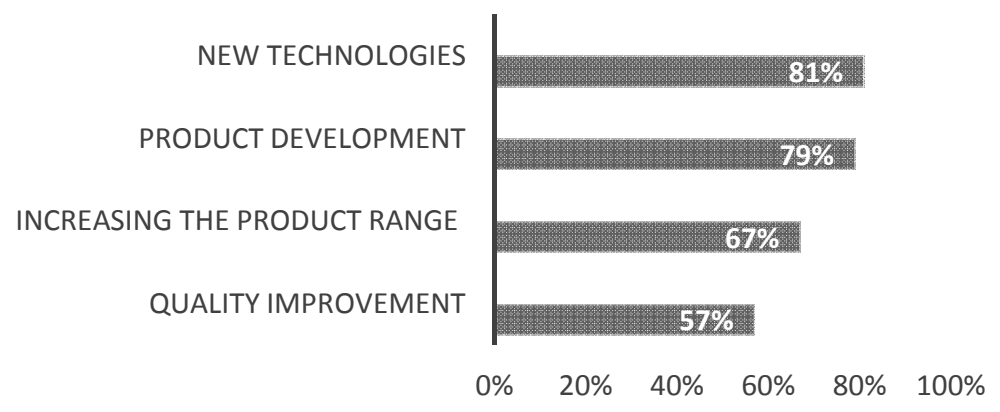

Fig. 5: Allocation of the acquired private equity capital spent by Polish companies in connection with the product

Source: Own work based on the answers to a survey prepared by authors.

Ilona FAŁAT-KILIJAŃSKA and Piotr LUTY (2019), Journal of Financial Studies \& Research, DOI: $10.5171 / 2019.630543$ 
Already during the process of selecting investment projects, the fund pays particular attention to the marketing department. It scrutinises the person at the position of marketing director, as experience in building and implementing marketing strategies constitutes perhaps the greatest competitive advantage a company can have. This may decide the success of the entire project. Marketing activities are very expensive; therefore, companies with insufficient capital resources often decide to limit them to a minimum or even give them up altogether. The capital received from a private equity fund provides managers with new possibilities, which until this point, they could not afford. For as it turns out, in the case of $40 \%$ of the surveyed entities, there has occurred an increase in the share of expenditure on marketing in sales revenues (fig. 6).

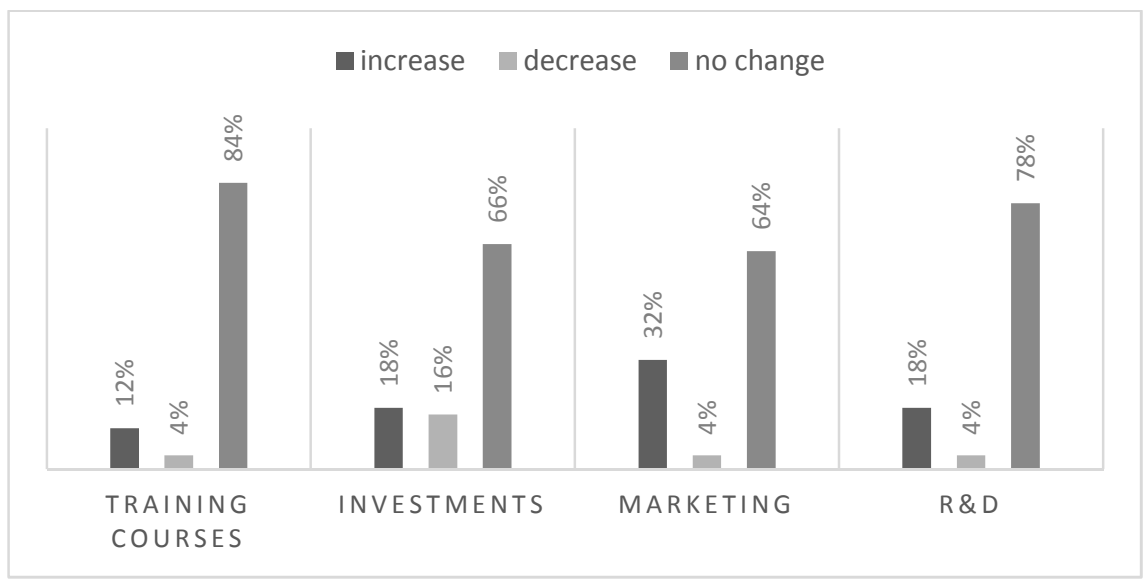

Fig. 6: The change in the share of expenditure on training, investments, marketing and R\&D in sales revenues in companies using private equity

Source: Own work based on the answers to a survey prepared by authors.

Moreover, increases in investment spending (including the purchase of management support IT systems) as well as in expenditure on research and development were noted. It is particularly important to strengthen the research activities of Polish businesses, as they constitute the most neglected part of the Polish economy. A relatively large increase was also observed in the expenditure on employee training. As mentioned above, upgrading the skills of all employees is also a major factor in increasing a company's competitiveness.

Having an investor in the form of a private equity fund enforces a specific approach to marketing. Most of the surveyed companies (more than 60\%) invest in creating the company's brand and/or building new distribution channels. For instance, in the case of Wroclaw-based TETA S.A. a part of the funds obtained from the sale of the company's shares was allocated to an aggressive advertising campaign in the public media (television, professional magazines) aiming at creating an expert image of TETA as a company specialising in HRM- and ERPtype software. This marketing strategy allowed them to build a good media image of the company, positive enough to give it a chance to survive the hardships of restructuring without any serious problems and to successfully debut on the Warsaw Stock Exchange (in 2010, TETA S.A became 
part of a Dutch group - UNIT4, and at that point, it was delisted from the Warsaw Stock (www.unit4.com/pl)). When it comes to other ways of using private equity capital on marketing activities, it is also worth noting the repositioning of the company's existing products ( $41 \%$ of the answers).

In building a company's value, in addition to the amounts spent on core activities of the business (production, marketing or finances), it is also important to create a positive corporate image. Almost $80 \%$ of the respondents paid attention to increasing the expenses aimed at improving the company's image. Other aspects that the capital acquired from a private equity fund is allocated to include: improving labour productivity, employing highly qualified workers, improving the quality of customer service and changing the organisational structure (fig. 7).

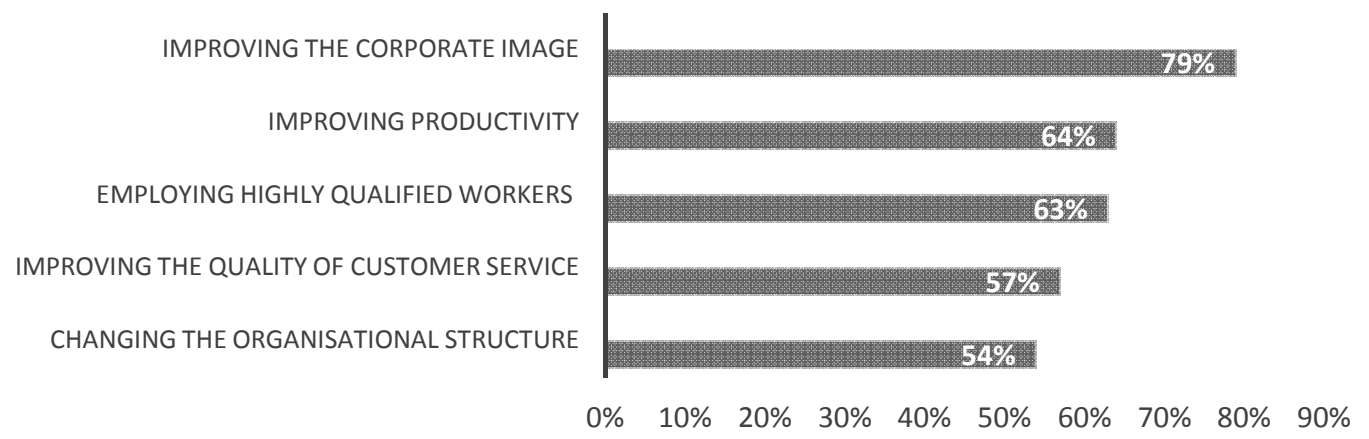

\section{Fig. 7: Allocation of private equity capital spent in connection with areas other than the product, marketing and finances}

Source: Own work based on the answers to a survey prepared by authors.

Those managing companies cooperating with a private equity fund need to switch to a new way of thinking. The author's question as to whether the company's functioning had changed after a private equity fund's entry was answered conclusively: some areas of the company's functioning changed completely. Although private equity funds generally do not engage in direct management of the company, they do need a lot of information regarding it to be able to exercise supervision over its business. The reports required of companies usually take form of monthly lists of the most important events, including financial and market aspects. In many cases, preparation of these reports forces the company to purchase corresponding analytical IT tools, which in turn imposes a change in the organisation of the entire company.

A Research conducted by European Private Equity and Venture Capital Association (EVCA (cf. 2002 EVCA survey.... ) shows that one of private equity investments' effects is an increase in employment. It is particularly evident in young enterprises or those having just started their business activity. The situation is somehow different in Polish businesses. Merely $58 \%$ of the respondents observed an increase in the level of employment in Polish companies. What is even more surprising is the high proportion of responses indicating that, compared with the year the investor entered the company, there occurred a decrease in employment as much as $37 \%$. This may suggest there is a

Ilona FAŁAT-KILIJAŃSKA and Piotr LUTY (2019), Journal of Financial Studies \& Research, DOI: $10.5171 / 2019.630543$ 
need to reorganise or even restructure the company taken on by the fund's representatives. It may also be due to the fact that private equity funds operating in the Polish market often acquired shares in already privatised enterprises (e.g. Stomil Sanok, Polfa Kutno, Zelmer). At the time, restructuring was an essential element of the investment programme.

Along with changes in the employment level, shifts in the organisational structure do occur. New departments are created (provided they had not already existed before the investor's entry): marketing, controlling, product development, human resources development management (HR). The author's studies show that employees of companies using private equity financing receive better salaries. In most of the Polish companies included in the study, after the fund's investment, the remuneration level increased. As indicated by more than $50 \%$ of the respondents, the remuneration standard rose at all steps of the corporate ladder highest in the case of middle-level management staff. A decrease in the salary level was indicated by more than $10 \%$ of the respondents, where most answers (15\%) referred to senior management staff (members of the board mainly). Moreover, the changes in the level of employee remuneration, especially that of senior management staff, may be connected with the introduction of new solutions in the incentive system.

Many of the surveyed managers stated that the salaries became dependent (in its socalled variable part) on the performance achieved by a given unit; frequently, managerial options programmes were introduced. Apart from the management staff, also other employees can participate in options programmes.

$94 \%$ of the Polish respondents stated that without private equity capital, their businesses would have grown more slowly or ceased to exist altogether (as many as 31\% of the responses in this case). The significance of private equity funds for the very existence of a given company in a market and the degree of its development is therefore enormous.

\section{Conclusions}

In order for a company to develop, it needs to be innovative. However, the company must first reach the right level of employment and turnover. In turn, in order for a company to reach this appropriate level, sufficient capital resources are necessary. A private equity fund provides primarily this last element, thus becoming the company's largest shareholder. The information provided by the companies participating in the author's survey clearly shows that they pay particular attention to the level of expenditure on research and development, marketing, products, improving productivity, the quality of employees and their training. The companies also point out that without a fund's contribution, the investments made by them would have certainly been much smaller. They would not have been able to afford engaging in research and development or increasing employment. The level of exports would have also been lower indicated mostly by half of the respondents.

The most frequently mentioned results of private equity's presence in the company include: increased financial liquidity, rapid development of new products, creation of the company's image and brand, employment of highly skilled workers, implementation of an information system supporting cost management and monitoring.

In addition to the capital, the fund brings shareholding companies many extra benefits. The surveyed entrepreneurs rated the following the highest: assistance in building the company strategies, assistance in company management, the possibility to maintain contacts with business relations of the fund's representatives, financial consultancy and the managerial experience of the fund's representatives. 
The analysis of selected companies' activities demonstrated that all the entities had undergone far-reaching changes in the organisational structure and culture. The number of employees grew, new jobs (e.g. Chief Financial Officer and Marketing Director) and departments (e.g. Personnel Development Department and the Controlling Department) were created. In half of the cases, a new incentive system was introduced, and in some cases, at the fund's request, management options programmes were introduced.

To summarise the above considerations, it can be concluded that managers of companies having a private equity fund as an investor show a high degree of optimism; assessing the condition of their businesses to be much better than that of rival companies. Having a private equity investor gives them a sense of security, and the received capital is used in a more effective manner.

And finally, to emphasise the importance of private equity financing, it is worth noting that without such companies as Apple, eBay, Intel, Microsoft, Tesla might not ever have been founded.

\section{References}

2002 EVCA survey of PanEuropean Private Equity and Venture Capital Activity, symposium materials, Vienna 4th-6th June 2003.

Herman A., Szablewski A., (1999), “Orientacja na wzrost wartości współczesnego przedsiębiorstwa", [in]: Herman A., Szablewski A. (eds.), Zarzqdzanie wartościq firmy, Poltext, Warsaw.

Kolka H., (2005), "W nieustannym tworzeniu innowacji i oferowaniu innowacyjnych produktów szukaj swoich szans", GlobalEconomy.pl, Wydawnictwo Instytutu Analiz i Prognoz Gospodarczych, www.globaleconomy.pl/content/view/355/ 35.
Obłój K. (1998), Strategia organizacji. W poszukiwaniu trwałej przewagi konkurencyjnej, PWE, Warsaw.

Porter M.E. (1985), Competitive Advantage, Creating and Sustaining Superior Performance, New York

Rappaport A. (1999), Wartość dla akcjonariuszy. Poradnik menedżera i inwestora, WIG-Press, Warsaw.

Rocznik 2002, Polish Private Equity and Venture Capital Association, Warsaw 2003,www.ppea.org.pl.

Rocznik 2003, Polish Private Equity and Venture Capital Association, Warsaw 2004, www.ppea.org.pl.

Rocznik 2004, Polish Private Equity and Venture Capital Association, Warsaw 2005, www.ppea.org.pl.

Rocznik 2005, Polish Private Equity and Venture Capital Association, Warsaw 2006, www.ppea.org.pl.

Rocznik 2006, Polish Private Equity and Venture Capital Association, Warsaw 2007, www.ppea.org.pl.

Rocznik 2007, Polish Private Equity and Venture Capital Association, Warsaw 2008, www.ppea.org.pl.

Rocznik 2008, Polish Private Equity and Venture Capital Association, Warsaw 2009, www.ppea.org.pl.

Rocznik 2009, Polish Private Equity and Venture Capital Association, Warsaw 2010, www.ppea.org.pl.

Stankiewicz M. J. (2005), Konkurencyjność przedsiębiorstwa. Budowanie konkurencyjności przedsiębiorstwa w warunkach globalizacji, Dom Organizatora, Toruń. 
The Word Competitiveness Report 1994", Word Economic Forum, Lausanne.

www.3tscapital.com

www.ei.com.pl

www.evca.com

www.intelcapital.com

www.unit4.com/pl

www.vectra.pl

Ilona FAŁAT-KILIJAŃSKA and Piotr LUTY (2019), Journal of Financial Studies \& Research, DOI: $10.5171 / 2019.630543$ 